\title{
INTEGRASI MODERASI BERAGAMA DALAM PEGEMBANGAN KURIKULUM PENDIDIKAN AGAMA ISLAM
}

\section{INTEGRATION OF RELIGIOUS MODERATION IN THE DEVELOPMENT OF THE ISLAMIC RELIGIOUS EDUCATION CURRICULUM}

\author{
Suprapto \\ Puslitbang Pendidikan Agama dan Keagamaan, Badan Litbang dan Diklat, Kementerian Agama RI \\ email: supraptolitbang@gmail.com
}

Naskah Diterima: 17 Februari 2020; Direvisi: 19 Juli 2020; Disetujui: 15 Desember 2020

\begin{abstract}
In the midst of the strengthening of the discourse on character education, religious moderation, and countering religious radicalism and terrorism, the study of Islamic religious education in public schools based on Islamic boarding schools is interesting to do. In this context, various problems arise related to the material and content of the Islamic religious education curriculum (PAI). Education under pesantren is no longer directed at the mastery of religious knowledge but also general science. This of course has an impact on shifting curriculum content and its implementation. This study uses a descriptive qualitative approach based on empirical phenomena. Data were collected through interviews, involved observations, questionnaires, documentation, and literature review. This research produces a model for implementing religious moderation education through the development of the PAI curriculum to present a moderate Islamic movement among students that teaches: (1) building tolerance among different groups of students, both outside Islam and within Islam; (2) spreading peace in their social environment; (3) prioritizing interfaith dialogue and (4) instilling openness with outside parties and 4) rejecting hate speech (hoaxes) both inside and outside schools. This study recommends the importance of teaching and practicing religious moderation among students to present moderate Islamic movements and habituation of noble morals.
\end{abstract}

Keywords: Curriculum PAI; Integration; Religious Moderation

\begin{abstract}
Abstrak
Di tengah menguatnya wacana pendidikan karakter, moderasi beragama, serta penanggulangan radikalisme dan terorisme bernunsa agama, kajian pendidikan agama Islam di sekolah umum berbasis pondok pesantren menarik untuk dilakukan. Dalam konteks ini muncul berbagai masalah terkait dengan materi dan muatan kurikulum pendidikan agama Islam (PAI). Pendidikan di bawah pesantren tidak lagi diarahkan pada penguasaan ilmu agama saja melainkan juga ilmu umum, Hal ini tentu berdampak pada pergeseran muatan kurikulum dan implementasinya. Penelitian ini menggunakan pendekatan kualitatif deskritif berdasarkan fenomena empirik. Data dikumpulkan melalui wawancara, pengamatan terlibat, angket, dokumentasi, dan kajian pustaka. Penelitian ini menghasilkan model penyelenggaraan pendidikan moderasi beragama melalui pengembangan kurikulum PAI untuk menghadirkan gerakan Islam moderat di kalangan peserta didik yang mengajarkan: (1) membangun toleransi di antara kelompok peserta didik yang berbeda, baik di luar Islam maupun di dalam Islam; (2) menebarkan perdamaian di lingkungan sosialnya; (3) mengedepankan dialog antar agama dan (4) menanamkan sikap keterbukaan dengan fihak luar dan 4) menolak ujaran kebencian (hoax) baik didalam dan luar sekolah. Penelitian ini merekomendasikan pentingnya mengajarkan dan mengamalkan moderasi beragama di kalangan peserta didik untuk menghadirkan gerakan Islam moderat dan pembiasaan berakhlak mulia.
\end{abstract}

Kata kunci: Kurikulum PAI; Integrasi; Moderasi beragama 


\section{PENDAHULUAN}

Munculmya fenomena di dunia pendidikan hadirnya sekolah umum (SD, SMP, dan SMA/SMK) di pondok pesantren. Dengan sistem pendidikan ini masyarakat memandang bahwa putra-putrinya akan memiliki 2 (dua) keuntungan sekaligus, yakni penguasaan pelajaran umum dan pendalaman pendidikan agama. Bahkan siswa/santri juga memperoleh bimbingan keterampilan untuk kemandirian ekonomi serta pembentukan karakter yang didasarkan atas ajaran agama. Ini memang bukan fenomena yang sepenuhnya baru, karena KH Wahid Hasyim telah mendirikan SMP di lingkungan Pondok Pesantren Tebuireng pada tahun 1950-an. Selain sekolah umum di Pondok Pesantren, kini berkembang pula Sekolah Umum Boarding School (SD, SMP, SMA) yang dikelola oleh masyarakat. Lembaga pendidikan jenis baru ini tidak dalam bentuk pesantren (dalam pengertian kajian kitab kuning), tetapi memberikan bimbingan keagamaan secara intensif kepada siswa. Dengan demikian, system boarding telah memberikan nilai tambah pendidikan agama dengan berbagai bentuknya (tahfidz al Quran, qiraat, kajian agama, praktik ibadah, latihan pidato, dll), sehingga kurikulum pendidikan agama Islam dalam system ini mengalami penguatan secara signifikan.

Kini terdapat pula sekolah umum (SD, SMP, SMA/SMK) yang berdiri sebagai bagian dari Pondok Modern. Bila umumnya pondok modern mendirikan madrasah (Ibtidaiyah, Tsanawiyah, dan Aliyah), kini hadir muncul pondok modern dengan lembaga pendidikan dalam jenis sekolah umum. Hal ini dilakukan untuk menampung aspirasi masyarakat yang menghendaki anaknya sekolah di lembaga pendidikan umum tetapi berbasis pesantren modern. Lembaga jenis ini antara lain hadir di Banten, seperti pondok moderen La Tansa di Rangkasbitung. Seperti jenis Sekolah Umum Boarding School, lembaga ini juga mempelajari ilmu agama secara lebih intensif, berikut dengan tradisi pesantren yang dengan kokoh diberlakukan. Tipology lain yang juga berkembang di masyarakat adalah pondok pesantren yang murni mengajarkan ilmu agama (tafaqquh fi al-din) tetapi para santrinya merupakan siswa sekolah di berbagai jalur dan jenjang, bahkan terdapat pula mahasiswa.
Dalam model ini, santri secara utuh belajar materi ilmu-ilmu umum di sekolah atau madrasah dan perguruan tinggi, tetapi di luar jam sekolah digembleng dalam penguasaan ilmu agama. Di samping memiliki keuntungan ekonomis (tidak harus ngontrak, dan berbiaya murah), siswa juga memperoleh kelebihan lain dalam bentuk penguasaan dan pendalaman ilmu agama.

Kemunculan berbagai tipologi tersebut sebagai jawaban terhadap terjadinya dikotomi pendidikan di Indonesia, di mana ada pendidikan umum (sekolah) di bawah Kementerian Pendidikan dan Kebudayaan dan Pendidikan Keagamaan seperti Pondok Pesantren dibawah pembinaan Kementerian Agama. Pendidikan umum (sekolah) lebih menitikberatkan pada pengembangan ilmu pengetahuan dan teknologi (Iptek), sedangkan pendidikan keagamaan berpegangteguh pada tafaqquh fiddin. Masyarakat atau orangtua menginginkan agar anaknya selain memiliki kemampuan iptek, juga imtak. Berbagai tipologi tersebut juga didorong meningkatnya jumlah kelas menengah ke atas masyarakat Muslim Indonesia yang tidak puas dengan pelayanan pendidikan yang tersedia.

Di tengah menguatnya wacara pendidikan karakter, moderasi beragama, serta penanggulangan radikalisme dan tetorisme bernunsa agama, kajian terhadap Pendidikan Agama Islam di sekolah umum berbasis pondok pesantren ini menarik dilakukan. Dalam konteks ini muncul berbagai masalah terkait dengan materi dan muatan kurikulum Pendidikan Agama Islam (PAI), yakni: seberapa jauh Pendidikan Agama Islam (PAI) diberikan kepada pada siswa/santri; apa latar belakang dilakukannya pengembangan pembelajaran PAI; apa sumber utama bacaan yang digunakan dalam pengembangan PAI; bagaimana strategi pembelajaran dilakukan; materi apa saja yang dilakukan dalam membentuk karakter keagamaan santri; apa kualifikasi tenaga pengajar PAI di masingmasing sekolah; dan bagaimana pengembangan kurikulum PAI diarahkan pada terbentuknya paham keagamaan yang moderat (moderasi beragama). Berbagai pertanyaan ini akan menghasilkan data dan analisis yang beragam, serta dapat dikembangkan dalam bentuk 
kebijakan pengelolaan pondok pesantren dan pengembangan muatan kurikulum Pendidikan Agama Islam di Sekolah Umum.

Pada sekolah berbasis pesantren, pembelajaran tidak lagi diarahkan pada penguasaan ilmu agama tetapi lebih ke ilmu umum, Hal ini tentu berdampak pada pergeseran muatan kurikulum dan implementasinya. Di samping itu, disinyalir ada beberapa muatan kurikulum atau implementasi pembelajaran PAI yang memiliki kecenderungan "ekslusif dan kaku", tidak mencerminkan praktik moderasi beragama. Salah satu hasil penelitian merekomendasikan bahwa sudah saatnya ceramah keagamaan sepihak, pidato kebencian, terorisme melalui cyber-net perlu diintervensi oleh negara melalui regulasi dan pengawasan yang relevan. Selain itu, orang tua perlu meningkatkan kewaspadaan dampak negatif teknologi dan membangun lebih banyak kebersamaan dengan mengembangkan nilai-nilai agama yang moderat dalam keluarga (Haryani, 2020). Penerapan boarding school yang mengadopsi pola pondok pesantren menjadi alternatif bagi sebagian orang tua terutama kelas menengah atas untuk menitipkan pendidikan putraputrinya. Namun demikian, biaya pendidikan yang sangat inggi pada model boarding ini, sehingga masih dikeluhkan sebagian masyarakat. Berdampingannya sekolah umum dan madrsah pada pondok pesantren ini, pada sebagian kasus menggeser peminatan ke madrasah sehingga siswa madrasah mengalami penurunan jumlah secara signifikan. Pondok pesantren yang murni mengajarkan ilmu agama (tafaqquh fi al-din) tetapi para santrinya merupakan siswa sekolah di berbagai jalur dan jenjang, bahkan terdapat pula mahasiswa. Dalam model ini, santri secara utuh belajar materi ilmu-ilmu umum di sekolah sedangkan materi agama diajarkan di pondok pesantren. Kondisi ini juga memberikan pengaruh pada sulitnya membentuk akhlaw siswa karena terkontaminasinya dengan lingkungan luar.

Permasalahannya, Bagaimana model inovasi kurikulum PAI di SMA berbasis pondok pesantren; Bagaimana arah dan tujuan pengembangan kurikulum PAI; Bagaimana respons siswa terhadap pengembangan kurikulum PAI; Bagaimana pengembangan kurikulum PAI bernuansa moderasi beragama dan Bagaimana implementasi kurikulum PAI dalam kegiatan pembelajaran.

Sejalan dengan rumusan masalah tersebut, maka tujuan penelitian ini adalah: Mengetahui model inovasi kurikulum pendidikan agama Islam di SMA berbasis pondok pesantren; Mengetahui arah dan tujuan pengembangan kurikulum PAI; Mengetahui respons siswa SMA di pondok pesantren terhadap pengembangan kurikulum PAI; Mengetahui pengembangan kurikulum PAI bernuansa moderasi beragama; Mengetahui implementasi kurikulum PAI dalam kegiatan pembelajaran. Berrdasarkan tujuan tersebut, maka siginifikansi penelitian ini menjadi penting untuk memberikan manfaat bagi penyelenggara pendidikan tingkat SMA di pondok pesantren dalam penyiapan dokumen kurikulum dan penerapannya, orang tua peserta didik dan masyarakat untuk memperoleh informasi terkait kurikulum yang digunakan dan penerapannya dalam pembelajaran; dan pemerintah, dalam hal ini Kementerian Agama untuk pengambilan kebijakan terkait dokumen kurikulum dan penerapannya yang bernuansa moderasi beragama pada pembelajaran PAI.

\section{KAJIAN TEORI}

\section{Konsep Integrasi}

Integrasi berasal dari kata Integration, yang berarti pembauran hingga menjadi keasatuan yang utuh dan bulat. Integrasi juga berarti proses mengkoordinasikan berbagai tugas, fungsi dan bagian-bagian sedemikian rupa dapat bekerjasama dan tidak saling bertentangan dalam pencapaian sasaran dan tujuan. Pendekagtan integrasi adalah menghubungkan dan menyatukan antara dua hal atau lebih (materi, pemikiran atau pendekatan). Pendekatan interkoneksi adalah memepertemukan dan menghubungkan 2 (dua) hal atau lebih (materi, pemikiran dan pendekatan karena tidak mungkin untuk dilakukan penyatuan integrasi (Agama, 2019).

Dalam implementasinya konsep integrasi dapat dilakuykan dalam berbagai level, yaitu: (1) Level filosofis. Integrasi dan interkoneksi pada level filosofis dalam wacana keiulmuan, bahwa di dalamnya harus diberikan nilai fundamental eksistensial dalam kaitannya 
dengan disiplin keilmuan lain dan dalam hubungannya dengan nilai-nilai humanistic. (2) Level materi. Integrasi dan interkoneksi dilakukan 3 (tiga) model, yaitu: pertama, model pengintegrasian ke dalam paket kurikulum, Kedua, model penanaman disiplin ilmu yang menunjukkan hubungan antara disiplin ilmu umumdan keislaman. Ketiga, model pengintegrasian ke dalam pengajaran disiplin ilmu. (3) Level metodologi. Integrasi dengan disiplin ilmu lain, misalnya psikologi dengan nilai-nilai Islam, maka secara metodologis ilmu interkonektif tersebut harus menggunakan pendekatan dan metode yang aman bagi ilmu tersebut. Level strategi. Level pelaksanaan integrative-interkonektif. Dalam konteks ini, setidaknya kualitas keilmuan serta keterampilan pengajar menjadi kunci keberhasilan pembelajaran berbasis paradigma interkoneksitas. Disamping kualitas-kualitas ini, pengajar harus difasilitasi dengan baik menyangkut pengadaan sumber bacaan yang harus beragam srta bahan-bahan pengajaran (teaching resources) di kelas.

\section{Pengertian Moderasi Beragama}

Pendidikan merupakan salah satu faktor penting dalam membentuk peradaban bangsa. Dengan pendidikan melahirkan perubahan dalam bidang ilmu pengetahuan dan teknologi. Di sisi lain pendidikan berfungsi mengembangkan kemampuan dan membentuk karakter serta peradaban bangsa yang bermartabat dalam mencerdaskan kehidupan bangsa dan bertujuan untuk berkembangnya potensi perserta didik agar menjadi manusia yang beriman dan bertakwa kepada Tuhan Yang Maha Esa, berakhlak mulia, sehat, berilmu, cakap, kreatif, mandiri, dan menjadi warga Negara yang demokratis serta bertanggung jawab (Undang-undang No.20 Tahun 2003 Pasal 3 tentang Sistem Pendidikan Nasional). Dengan demikian pendidikan karakter akan membangun moral peserta didik berbasis etika dan budaya bangsa yang sudah tertanam dan menjadi ciri khas bangsa Indonesia. Oleh sebab itu satuan pendidikan merupakan salah satu aspek penting dalam pembangunan karakter. Karakter sesorang berkaitan dengan kepribadian yang merupakan ciri atau karakteristik dari diri seseorang yang bersumber dari bentukan-bentukan yang diterima dari lingkungan, misalnya keluarga pada masa kecil, dan juga bawaan sejak lahir. Thomas Lickona mengartikan karakter sebuah kekuatan batin dalam menanggapi sesuatu secara bermoral. Agama merupakan acuan utama yang membawa untuk membentuk kehidupan yang bermoral. Meskipun agama memiliki banyak perbedaan mengenai apa yang harus dilakukan umatnya dalam beribadah, mereka semua memiliki kesamaan prinsip bahwa setiap tindakan yang mereka lakukan dalam hidup ini termasuk pilihan akan perilaku moral yang akan memberikan dampak sebanding di masa yang akan datang (Misrawi, 2010)

Dalam buku Moderasi Beragama (Agama, 2019), kata moderation sering digunakan dalam pengertian average (rata-rata), core (inti), standard (baku), atau non-aligned (tidak berpihak). Secara umum, moderat berarti mengedepankan keseimbangan dalam hal keyakinan, moral, dan watak, baik ketika memperlakukan orang lain sebagai individu, maupun ketika berhadapan dengan institusi negara. Kalau dianalogikan, moderasi adalah ibarat gerak dari pinggir yang selalu cenderung menuju pusat atau sumbu (centripetal), sedangkan ekstremisme adalah gerak sebaliknya menjauhi pusat atau sumbu, menuju sisi terluar dan ekstrem (centrifugal). Ibarat bandul jam, ada gerak yang dinamis, tidak berhenti di satu sisi luar secara ekstrem, melainkan bergerak menuju ke tengah-tengah (Purwanto et al., 2019).

Dalam konteks beragama, sikap moderat adalah pilihan untuk memiliki cara pandang, sikap, dan perilaku di tengah-tengah di antara pilihan ekstrem yang ada, sedangkan ekstremisme beragama adalah cara pandang, sikap, dan perilaku melebihi batas-batas moderasi dalam pemahaman dan praktik beragama. Karenanya, moderasi beragama kemudian dapat dipahami sebagai cara pandang, sikap, dan perilaku selalu mengambil posisi di tengah-tengah, selalu bertindak adil, dan tidak ekstrem dalam beragama. Moderasi Islam dalam bahasa Arab disebut dengan alWasathiyyah alIslamiyyah. Al-Qardawi menyebut beberapa kosa kata yang serupa makna dengannya termasuk katan Tawazun, I'tidal, Ta'adul dan Istiqamah. Sementara dalam bahasa inggris sebagai Islamic Moderation. 
Moderasi Islam adalah sebuah pandangan atau sikap yang selalu berusaha mengambil posisi tengah dari dua sikap yang berseberangan dan berlebihan sehingga salah satu dari kedua sikap yang dimaksud tidak mendominasi dalam pikiran dan sikap seseorang. Dengan kata lain seorang Muslim moderat adalah Muslim yang memberi setiap nilai atau aspek yang berseberangan bagian tertentu tidak lebih dari porsi yang semestinya. Adapun istilah moderasi menurut Khaled Abou el Fadl dalam The Great Theft adalah paham yang mengambil jalan tengah, yaitu paham yang tidak ekstem kanan dan tidak pula ekstrem kiri (Misrawi, 2010). Islam selalu bersikap moderat dalam menyikapi setiap persoalan, bahkan prinsip moderasi ini menjadi karakteristik Islam dalam merespon segala persoalaan (Setiyadi, 2012).

Inti dari moderasi beragama adalah adil dan berimbang dalam memandang, menyikapi, dan mempraktikkan semua konsep yang berpasangan di atas. Dalam KBBI, kata "adil" diartikan: 1) tidak berat sebelah/tidak memihak; 2) berpihak kepada kebenaran; dan 3) sepatutnya/ tidak sewenang-wenang. Sedangkan keseimbangan, adalah istilah untuk menggambarkan cara pandang, sikap, dan komitmen untuk selalu berpihak pada keadilan, kemanusiaan, dan persamaan. Kecenderungan untuk bersikap seimbang bukan berarti tidak punya pendapat (Agama, 2019:19). Moderasi tidak hanya diajarkan oleh umat Islam saja melainkan juga yang beragama lain. Dalam kaitan ini toleransi beragama merupakan elemen dasar yang dibutuhkan untuk menumbuhkembangkan sikap saling memahami dan menghargai perbedaan yang ada dalam masyarakat majemuk seperti Indonesia. Peserta didik memiliki posisi penting dan potensi besar dalam menciptakan toleransi beragama (Qowaid, 2013). Moderasi mendorong terciptanya keseimbangan dalam kehidupan personal maupun hubungan antar manusia yang lebih luas. Di dunia pesantren, moderasi sudah menjadi karakter yang melekat pada pesantren dan semua penghuninya, pimpinannya, ustadznya sampai kepada para santri. Mereka sejak awal sudah mempraktekkan moderasi dalam beragama. Karena sudah menjadi ciri khas sejak dan contoh dari bagaimana wali songo menyebarkan Islam di Indonesia (Aziz, 2020).

\section{Pengelolaan dan Pengembangan Kurikulum}

Sekolah sebagai basis pendidikan dasar dan menengah menjadi titik awal penyemaian keagamaan peserta didik dari berbagai aliran, baik yang konservatif, (Hamid Hasan, 2008) (Frank S Meyer, 2015: 14), eklusif, radikal, (Mc, 2012) moderat, inklusif, pluralis dan bahkan liberal. (Michael Freeden, 2015:4). Dengan demikian sekolah menjadi sarana yang efektif dalam membangun pengetahuan, kesadaran, sikap, dan perilaku keagamaan, sehingga kontsruksinya mudah dilekatkan kepada paham keagamaan yang berkembang. Pandangan ini menjadi penting dalam pengembangan kurikulum PAI di sekolah

Kurikulum PAI merupakan seperangkat rencana dan pengaturan mengenai tujuan, isi, bahan, serta pembelajaran yang digunakan sebagai pedoman penyelenggaraan kegiatan pembelajaran untuk mrncapai tujuan pendidikan. Kurikulum PAI mencakup materi Al Quran, Hadits, Akidah, Akhlak, Fiqih, Tarikh dan Kebvuayaan Islam (Kemenag, 2012) (Shaleh: 2000)

Prinsip pengelolaan dan pengembangan kurikulum di sekolah mengacu pada kurikulum dasar yang telah di tetapkan oleh pemerintah sebagai acuan kegiatan pembelajaran dan pencapaian hasil yang telah ditetapkan. Kegiatan pembelajaran harus mampu mengintegrasikan penguassaaan teori, praktek dan pembiasaan akhlakul karimah melalui keteladanan. Arah pengembangan kurikulum dilakukan secara berkesinambungan, terpadu, berpusat pada potensi peserta didik, tanggap terhadap perkembangan ilmu dan sesuai dengan kebutuhan masyarakat. (Suprapto, 2017). Seiring dengan arah pengembangan kurikulum tersebut dalam pengembangan kurikulum perlu memperhatikan prinsip-prinsip fleksibilitas, berorientasi pada tujuan, efektifitas dan efesiensi dan kontinuitas. Fleksibilitas menitikberatkan pada pengembangan materi dan metodologi yang digunakan dalam proses pembelajaran. Hal yang harus diperhatikan adalah bagaimana mendapatkan pilihan yang tepat agar terjadi komunikasi yang baik antara guru dan siswa, sehingga materi yang diberikan benar benar dapat ditangkap dan dipahami. Oleh sebab itu, guru harus memperhatikan keberadaan siswa dari segi kecerdasan, 
kemampuan dan pengetahuan yang telah dikuasainya, kemudian membuat pilihan bahan belajar dan metode-metode pembejalaran yang tepat dan sesuai. Salah satunya dengan metode internalisasi melalui tatap muka dalam pembelajarn, tutorial, seminar dan yang semisalnya. Evaluasinya dilakukan melalui screening wawasan keislaman secara lisan dan tertulis (Qowaid, 2013) yang berorientasi pada tujuan, pemilihan kegiatankegiatan dan pengalaman belajar didasarkan pada ilmu pengetahuan dan pengembangan masyarakat. Oleh Karena itu, sebelum menentukan waktu dan bahan pelajaran terlebih dahulu ditetapkan tujuan yang harus dicapai oleh siswa dalam mempelajari suatu mata pelajaran. Efektifitas dan efisiensi, struktur kurikulum merupakan pelengkap dari pendidikan agama Islam yang diperoleh siswa pada lembaga pendidikan formal atau sekolah umum. Sehingga memerlukan keterampilan tersendiri dalam pengor-ganisasiannya agar waktu yang tersedia dapat dimanfaatkan secara efektif dan efisien tanpa mengurangi capaian tujuan yang diharapkan. Kontinuitas, kurikulum dikembangkan dengan pendekatan hubngan hirarki fungsional yang menghubungkan antar jenjang dan tingkatan. Oleh sebab itu, perencanaan kegiatan belajar mengajar harus dibuat secara optimal dan sistematis, sehingga kemungkinan terjadinya proses peningkatan, perluasan serta pengalaman yang terus berkembang dari suatu pokok bahasan mata pelajaran. (Deepwell, 2002).

Pembelajaran di sekolah berbasis pondok pesantren meliputi kegiatan kurikuler dan ektrakurikuler. Kegiatan kurikuler mengacu pada materi dan alokasi waktu yang telah ditetapkan dalam struktur kurikulum yang dituangkan dalam Kompetensi Inti (KI) dan Kompetensi Dasar (KD) pada setiap mata pelajaran. Sedangkan kegiatan ekstra kurikuler merupakan kegiatan yang dikembangkan sekolah di luar jam pelajaran dengan tujuan untuk memperkuat kegiatan kurikuler pada seluruh aspek yaitu: pengetahuan, sikap dan ketrampilan. Kegiatan ini dilakukan secara terprogram dengan memperhatikan relevansinya dengan tujuan pendidikan yang telah ditetapkan. Pendidikan agama menjadi mata pelajaran wajib yang diajarkan dalam kurikulum sekolah baik ditingkat sekolah dasar sampai dengan sekolah menengah. Sekolah memperkenalkan nilai nilai agama Islam melalui mata pelajaran agama Islam di dalam kelas oleh guru pendidikan agama Islam dan berbagai kegiatan ekstra kurikuler di bawah bimbingan guru yang ditugasi. (Agama, 2019). Dalam hal ini pentingnya proses pembelajaran yang bermutu dapat mengantarkan peserta didik mencapai hasil belajar yang optimal tidak hanya dari segi pengetahuan tetapi juga beriman, bertaqwa dan berakhlak mulia serta memiliki keterampilan sesuai dengan keilmuannya. Untuk kurikulum, dengan adanya jam tambahan, materi pelajaran yang ditambah, sarana prasarana memadai dan penggunaan multimedia pembelajaran meningkatkan efektivitas dan efisiensi program (Handayani, 2017).

\section{Pendidikan Agama Islam}

Pendidikan agama merupakan pendidikan yang memberikan pengetahuan, keterampilan, dan membentuk sikap peserta didik dalam mengamalkan ajaran agama pada semua jalur, jenjang, dan jenis pendidikan. Secara umum pendidikan agama berfungsi untuk membentuk manusia Indonesia yang beriman dan bertakwa kepada Tuhan Yang Maha Esa serta berakhlak mulia dan mampu menjaga kerukunan hubungan antar umat beragama (Penjelasan Pasal 37 Undang-undang Nomor 20 Tahun 2003 tentang Sistem Pendidikan Nasional). Seiring dengan hal tersebut pendidikan agama Islam diajarkan untuk mewujudkan manusia yang bertakwa kepada Allah SWT dan berakhlak mulia serta bertujuan untuk menghasilkan manusia yang jujur, adil, berbudi pekerti, etis, saling menghargai, disiplin, harmonis, dan produktif baik personal maupun sosial.

Pendidikan di sekolah dalam prespektif Islam idealnya mampu menumbuhkan kecerdasan anak menuju pada kecerdasan fathonah, siddiq, amanah dan tabligh sebagaimana karakter nabi Muhammad saw, pendidikan karakter dalam perspektif Islam adalah pembentukan akhlaqul karimah sebagaimana sifat-sifat Rosululloh saw yakni siddiq (benar perkataan maupun perbuatannya), amanah (benar-benar dapat dipercaya bukan sebagai pembohong), Tabligh (penyampai kebenaran dan pencegah kemungkaran) dan 
fathonah (cerdas bukan bodoh). Salah satu upaya menerapkan pendidikan karakter di sekolah dengan melakukan kolaborasi dengan komunitas keagamaan tertentu yang mampu menumbuhkan semangat kerohanian, memiliki pemahaman dan praktik ajaran keimananyang baik dan benar serta toleran. Kerjasama dengan komunitas keagamaan ini dapat dilakukan dengan melibatkan lembaga-lembaga yang memang mennyediakan layanan untuk mengembangkan keagamaan khusus, sesuai dengan agama masing-masing peserta didik (Kemendikbud, 2017)

Bentuk-bentuk keseimbangan dalam Islam dapat diklasifikasikan ke dalam berbagai ragam pranata kehidupan beragama sebagai berikut: 1. Keseimbangan teologi 2. Keseimbangan ritual keagamaan 3. Keseimbangan moralitas dan budi pekerti 4 . Keseimbangan proses tasyri' (pembentukan hukum) (Yasid, 2014). Keseimbangan hendaknya dapat ditegakkan dan dilaksanakan oleh semua orang, karena apabila seseorang tidak bisa menegakkan sikap seimbang akan melahirkan berbagai masalah. Agama senantiasa menuntut segala aspek kehidupan kita untuk seimbang, tidak boleh belebihan dan tidak boleh kekurangan.

Dalam pembelajaran pendidikan karakter telah masuk ke dalam kurikulum tingkat satuan pendidikan (KTSP), silabus dan rencana program pembelajaran (RPP). Prinsip yang digunakan dalam pengembangan pendidikan karakter adalah: (1) Berkelanjutan: mengandung makna bahwa proses pengembangan nilai-nilai karakter merupakan proses yang tiada henti, dimulai dari awal peserta didik masuk sampai selesai dari suatu satuan pendidikan bahkan sampai terjun kemasyarakat (2) Melalui semua mata pelajaran pengembangan diri dan budaya sekolah serta muatan local (3) Nilai tidak diajarkan tapi dikembangkan dan dilaksanakan, (Kemenag, 2014).

Pada tataran praktis, belajar sebagai pengalaman pengetahuan akan mengalami perubahan dari pengetahuan yang sederhana ke arah pengetahuan yang lebih kompleks. Syaiful Sagala (2003:57), Oleh karena itu, belajar selalu dimulai dari suatu masalah dan berlangsung sebagai usaha untuk memecahkan masalah tersebut serta berhasil bila disadari telah ditemukan hubungan diantara unsur-unsur masalah tersebut. Menurut Trianto (2009:17), belajar merupakan proses perubahan perilaku tetap dari belum tahu menjadi tahu, dari tidak faham menjadi faham, dari kurang terampil menjadi lebih terampil, dan dari kebiasaan lama menjadi kebiasaan baru, serta bermanfaat bagi lingkungan maupun individu itu sendiri. Belajar dalam konteks ini mencakup perubahan yang terjadi pada aspek kognitif, afektif dan aspek psikomotorik (Trianto, 2009).

Pendidikan karakter di sekolah dalam prespektif Islam melalui proses belajar mengajar, pembiasaan dan didukung oleh lingkungan dan ekstra kurikuler, Dengan demikian peserta didik mampu menumbuhkan kecerdasan anak menuju pada kecerdasan fathonah, siddiq, amanah dan tabligh sebagaimana karakter nabi Muhammad saw.

Pembentukan pendidikan karakter keagamaan model pendidikan karakter di sekolah melalui pembiasaan dan didukung oleh lingkungan dan ekstra kurikuler, Dengan demikian peserta didik memahami pendidikan karakter dan dapat membentuk pembiasaan dan menerapkan pengetahuan pendidikan karakter. Untuk merealisasikan karakter mulia sangat perlu dibangun budaya yang dapat mempercepat terwujudnya karakter yang diharapkan. Atas dasar ini Kementerian Pendidikan dan Kebudayaan mencanangkan Gerakan Penguatan Pendidikan Karakter (PPK) secara bertahap mulai Tahun Ajaran 2016 sebagai bentuk perwujudan dari Rencana Pembangunan Jangka Menengah Nasional (RPJMN) Tahun 2015-2019 (Kemendikbud, 2016). Satuan pendidikan dalam hal ini merupakan sarana strategis bagi pembentukan karakter bangsa, karena memiliki sistem, infrastruktur, dan dukungan lainnya.

\section{Gambaran Umum Lokasi Penelitian}

SMA Ciledug Musaddadiyah Garut berlokasi di Jl. Mayor Syamsu Jayaraga Garut dibawah naungan Yayasan Al-Musaddadiyah merupakan sebuah yayasan yang didirikan oleh Prof. KH. Anwar Musaddad (Alm.) dan Ibu, Hj. Atikah Musaddad (Alm.) beserta putra-putrinya yang fokusnya untuk kegiatan dakwah dan institusi pendidikan. Yayasan ini didirikan 
dalam rangka partisipasi keluarga didalam upaya mencerdaskan kehidupan bangsa melalui penyelenggaraan lembaga pendidikan. Yayasan Al - Musaddadiyah didirikan berdasarkan Akte Notaris Aam Warlimah, SH, Nomor 25 tanggal 27 Agustus 1975 yang berdomisili di Garut.

Visi SMA Ciledug Al-Musaddadiyah Garut adalah prestasi meningkat, amanah, professional dalam melaksanakan tugas serta peduli terhadap pembaharuan/ lingkungan. Sedangkann misinya adalah meningkatkan proses belajar mengajar, mewujudkan peningkatan mutu, membina pencapaian akhlak/ budi pekerti luhur, mewujudkan personal yang sehat dan terampil beretos kerja, meningkatkan pelayanan/kerjasama secara optimal, meningkatkan budaya tertib dan budaya bersih dan melaksanakan pengawasan berkesinambungan.

Jumlah siswa empat tahun teakhir mulai tahun pelajaran 2015/2016 sampai dengan 2018/2019 mengalami kenaikan dan penurunan. Pada tahun pelahjaran 2015/2016 jumlah seluruh siswa 591 orang (330 Perempuan dan 261 Laki-laki), 2016/2017 berjumlah 558 orang (310 Perempuan dan 248 Laki-laki), 2017/2018 berjumlah 518 orang (266 Perempuan dan 252 Laki-laki) dan 2018/2019 berjumlah 536 orang (309 Perempuan dan 227 Laki-laki). Sedangkan jumlah rombongan belajar seluruhnya berjumlah 18 rombongan belajar dengan masing-masing kelas 6 rombongan belajar baik kelas X, XI maupun XII.

Jumlah tenaga pendidik seluruhnya 43 orang (9 orang PNS dan 37 orang tenaga honorer) dengan kualifikasi pendidikan 32 orang sarjana (S1) dan 11 orang Sarjana Muda (DIII/DIV). Adapun jumlah tenaga kependidikan seluruhnya berjumlah 23 orang (7 orang S1, 13 orang SLTA dan 3 orang SMP).

Sarana dan prasarana pendidikan yang dimiliki terdiri dari: gedung sekolah, ruang kelas, ruang guru, ruang Tata Usaha, ruang BK, ruang PMR, ruang UKS, ruang Paskibra, sanggar seni rupa, sanggar Pramuka, ruang IPMA, ruang OSIS, sarana pendidikan, computer, ruang perpustakaan, laboratorium internet dan laboratorium fisika, biologi dan kimia.
Prestasi sekolah yang telah diraih oleh guru berupa guru berprestasi, duta Indonesia ke Jepang, Festival Teater antar SLTA Se-Jabar, Pameran Lukisan. Sedangkan perstasi siswa terdiri dari PLS2N, MTQ, Pidato, dan PMR.

Program unggulan yang dikembangkan di sekolah ini adalah Fiqih Ibadah, Tahfidz Al Quran, Bahasa Arab dan BTQ. Fiqih Ibadah terdiri dari tata cara wudhu, praktek wudu, tata cara solat, praktek solat dan wirid setelah solat, praktek memandikan jenajah, tahlil. Tahfidzul Qur'an minimal 1juss maksima 3 Juzz (Juzz 30, 29 dan 1). Bahasa Arab, trgetnya siswa mampu untuk 1) qitabah, 2) Qiroah, 3) muhasadasah dalam kehidupan sehari-hari, 4) Al Istima' (mendengarkan dan dapat mengucap ulang dengan benar. BTQ, targetnya membaca Al Quran sesuai dengan Tajwit dan mampu menulis Al Quran dengan baik dan benar. Program unggulan ini menjadikan lulusannya berbeda dengan lulusan sekolah umum lainnya. Mereka memiliki perilaku yang religius, jujur, santun dan tegas. Dukungan sekolah terhadap kebijakan bidang agama adalah memfasilitasi kegiatan keagamaan dengan tempat ibadah di lingkungan sekolah berupa masjid. Juga kebijakan lainnya seperti menyediakan ruangan khusus yang digunakan untuk kegiatan keagamaan.

\section{METODOLOGI}

Penelitian ini menggunakan metode kualitatif deskriptif berdasarkan fenomena empirik (Creswell, 2014). Data dikumpulkan melalui wawancara, pengamatan terlibat, angket, dokumentasi, dan kajian pustaka. Penelitian deskriptif merupakan Langkahlangkah melakukan representative objek penelitian tentang gejala-gejala yang terdapat pada masalah penelitian Instrumen pengumpulan data disusun dalam bentuk pedoman umum wawancara dan Observasi yang disusun secara terstruktur, namun dapat dikembangkan lebih lanjut sesuai kondisi latar. Data meliputi sejarah lembaga (SMA dan Ponpes), jaringan kelembagaan, guru PAI, siswa, sarana prasarana pembelajaran, prestasi kelembagaan dan siswa (input dan output), inovasi kurikulum, model pembelajaran, dan bahan ajar yang digunakan. 
Penelitian ini dilakukan di SMA Ciledug Musaddadiyah Garut Jawa Barat. Adapun alasan pemilihan lokasi tersebut berdasarkan wilayah administrasi dan letak geografis dengan mem pertimbangkan daerah-daerah yang memiliki varian tingkat keragaman minoritas dan mayoritas pemeluk agamanya dan memiliki lembaga pendidikan umum berbasis pesantren.

\section{HASIL DAN PEMBAHASAN}

\section{Model Inovasi Kurikulum PAI Berbasis Pondok Pesantren}

Kurikulum PAI yang digunakan SMA Ciledug Al-Musaddadiyah Garut mengacu pada Kurikulum 2013 dari Kementerian Agama. Materi PAI berdasarkan Kurikulum 2013 mengandung lima unsur yaitu al-Qur'an, akidah, akhlak, fikih dan tarikh (sejarah kebudayaan Islam) yang disusun dan diajarkan pada tiap semesternya agar mempermudah guru PAI dalam menyampaikan materinya berdasarkan tingkat kemudahan dan kesulitan pada setiap kelasnya.

Secara umum kemampuan dasar yang harus dicapai pembelajaran PAI, yaitu: (1) Beriman kepada Allah Swt., dan lima rukun iman yang lain dengan mengetahui fungsi dan hikmahnya serta terefleksi dalam sikap, perilaku, dan akhlak peserta didik dalam dimensi vertikal maupun horizontal; (2) Dapat membaca, menulis dan memahami ayat Alquran serta mengetahui hukum bacaannya dan mampu mengimplementasikan dalam kehidupan seharihari; (3) Mampu beribadah dengan baik sesuai dengan tuntutan syariat Islam baik, ibadah wajib maupun ibadah sunnah; (4) Dapat meneladani sifat, sikap, dan kepribadian Rasulullah, sahabat, dan tabi in serta mampu mengambil hikmah dari sejarah perkembangan Islam untuk kepentingan hidup sehari-hari dimasa kini dan masa depan; (5) Mampu mempraktikkan system muamalat Islam dalam tata kehidupan bermasyarakat, berbangsa, dan bernegara.

Dalam pelaksanaannya, sekolah ini mengembangkan kurikulum PAI ke dalam kegiatan intra kurikuler dan ekstra kurikuler. Dalam kegiatan intra kurikuler berupa mata pelajaran P3AI (Program Pengembangan Pendidikan Agama Islam) yang terdiri dari program Fiqh Ibadah, tahfidz, BTQ, Aswaja dan bahasa Arab diberikan pada seluruh kelas. Sedangkan untuk kegiatan ekstra kurikuler berupa kegiatan Rohani Islam, Marawis, Karya Ilmiah Remaj, Keputrian dan Seni menulis indah.

Tabel 1. Kurikulum P3AI SMA Ciledug Al Musaddadiyah Garut Tahun Pelajaran 2019/2020

\begin{tabular}{|c|c|c|c|c|c|c|c|}
\hline \multirow{3}{*}{ No. } & \multirow{3}{*}{ Materi } & \multicolumn{6}{|c|}{ Kelas } \\
\hline & & \multicolumn{2}{|c|}{ I } & \multicolumn{2}{|c|}{ II } & \multicolumn{2}{|c|}{ III } \\
\hline & & 1 & 2 & 3 & 4 & 5 & 6 \\
\hline \multirow[t]{4}{*}{1} & Fiqih Ibadah & & & & & & \\
\hline & Toharoh & 2 & 2 & - & - & - & - \\
\hline & Sholat & - & - & 2 & 2 & - & - \\
\hline & Doa dan Dzikir & - & - & - & - & 2 & 2 \\
\hline \multirow[t]{4}{*}{2} & Tahfidz & & & & & & \\
\hline & Juz 29 & 2 & 2 & - & - & - & - \\
\hline & Jus 30 & - & - & 2 & 2 & - & - \\
\hline & Murajaah & - & - & - & - & 2 & 2 \\
\hline
\end{tabular}

Tabel 2. Target Hapalan SMA Ciledug Al-Musaddadiyah Garut Tahun Pelajaran 2019/2020

\begin{tabular}{lll}
\hline \multicolumn{1}{c}{ SEMESTER 1 } & & \multicolumn{2}{c}{ SEMESTER 2 } \\
\hline 1. Al - Mulk & 1. & Al-Jinn \\
2. Al-Qalam & 2. & Al-Muzammil \\
3. Al- Haqqah & 3. & Al-Muddasir \\
4. Al-Ma'arij & 4. & Al-Qiyamah \\
5. Nuh & 5. & Al-Insan \\
& 6. & Al-Mursalat \\
\hline
\end{tabular}




\begin{tabular}{lll}
\hline \multicolumn{1}{c}{ SEMESTER 3 } & & \multicolumn{1}{c}{ SEMESTER 4 } \\
\hline 1. An-Naba' & 1. & Adh-Dhuhaa \\
2. An-Naazi'aat & 2. & Al-Insyirah (Alam Nasyrah) \\
3. Abasa & 3. & At-Tiin \\
4. At-Takwiir & 4. & Al-'Alaq \\
5. Al-Infithaar & 5. & Al-Qadr \\
6. Al-Muthaffifin & 6. & Al-Bayyinah \\
7. Al-Insyiqaaq & 7. & Al-Zalzalah \\
8. Al-Buruuj & 8. & AL-'Adhiyaat \\
9. Ath-Thaariq & 9. & Al-Qaari'ah \\
10. Al-A'laa & 10. & At-Takaatsur \\
11. Al-Ghaasyiyah & 11. & Al-'Ashr \\
12. Al-Fajr & 12. & Al-Humazah \\
13. Al-Balad & 13. & Al-Fiil \\
14. Asy-Syams & 14. & AL-Quraisy \\
15. Al-Lail & 15. & Al-Maa'uun \\
& 16. & Al-Kautsar \\
& 17. & Al-Kaafiruun \\
& 18. & An-Nashr \\
& 19. & Al-Lahab \\
\multicolumn{1}{c}{ SEMESTER 5 } & 20. & Al-Ikhlash \\
& 21. & Al-Falaq \\
\hline Muroja'ah Semester 3 & 22. & An-Naas \\
\hline
\end{tabular}

Target dari masing-masing program P3AI adalah: untuk Fiqh ibadah: Wudu, sholat, saum (kelas); Ke NU-an (kelas 2); manasik haji, Waris, pengurusan jenazah. Tahfidz, targetnya kelas 1 dapat menghafal juz amma 30, kelas 2 juz 29; kelas 3 menghafal juz 1. Jadi selama tiga tahun dapat menghafal 3 juz. BTQ (Baca Tulis Al Quran), targetnya da akhirnya dapat membaca dan menulis al quran dengan benar. Aswaja diberikan pada mata pelajaran P3AI oleh semua guru. Bahasa Arab, targetnya minimal dapat mengerti kosa kata bahasa Arab.

Kegiatan ekstrakurikuler dan penguatan PAI dilakukan agar siswa tidak hanya memahami PAI secara kognitif, tetapi juga memiliki kemampuan pada aspek psikomotor dan afektif. Penguatan pembelajaran PAI melalui kegiatan ekstrakurikuler sesuai dengan minat dan bakat siswa berupa: kegiatan Rohani Islam (Rohis), marawis, KIR (Karya Ilmiah Remaja), Keputrian dan seni menulis indah (Kaligrafi). Untuk keputrian dilaksanakan setiap hari jumat pada saat jumatan. Pelaksanaannya da intergrasi antara sekolahn dengan pesantren.
Guru SMA Musaddadiyah diberikan pelatihan khusus dalam pembelajaran P3AI dilaksanakan selam 2 hari pada setiap tahun ajaran baru. Peserta didik yang belum lulus mata pelajaran P3AI maka kelulusannya ditangguhkan sampai mereka dinyatakan lulus pada mata pelajaran P3AI. Untuk menunjang pelaksanaan pengembangan kurikulum SMA Musaddadiyah melengkapai dengan sarana dan prasarana penyelenggaraan pendidikan agama Islam, seperti tersedianya 2 (dua) mesjid dengan kapasitas 3000 orang, buku teks dan penunjang PAI, kain kafan, boneka untuk pemandian jenajah, al Qur'an.

\section{Arah dan Tujuan Pengembangan Kurikulum PAI Berbasis Pondok Pesantren} Arah dan tujuan pengembangan kurikulum PAI di SMA Ciledug Al Musaddadiyah Garut untuk memenuhi tuntutan masyarakat terhadap pendidikan yang bermuatan nilai-nilai ke-Islaman. Disamping itu pendidikan agama Islam ditujukan untuk mewujudkan manusia yang bertakwa kepada Allah SWT, berakhlak mulia serta menghasilkan manusia yang jujur, adil berbudi 
pekerti, saling menghargai, disiplin, produktif, baoik personal maupun social (Rhozin, 2017).

Terdapat tiga materi penting PAI dalam mewujudkan anak sholeh, yaitu: a) Fiqh Ibadah: Wudhu, Tata cara sholat, bimbingan bagi siswa tentang tata cara sholat yang benar, Saum, KeNUan ; b) Pembimbingan BTQ, Bagi siswa yang belum bisa baca Al Qur'an diberi pembinaan oleh guru PAI sesuai tingkatan kemampuan siswa dan c) Pembiasaan Berperilaku Mulia (Akhlakul Karimah) dilakukan melalui kegiatan: Sholat Dhuha, Dzuhur, Ashar dan Sholat Jumat berjamaah; Pembacaan dzikir berjamaah setelah shalat; Berdoa sebelum pelajaran dimulai dan sebelum pulang. Sebelum pembelajaran di mulai siswa berdoa bersama terlebih dahulu, diawali membaca fatihah dan ikrar serta do'a mulai belajar. Membiasakan berjabat tangan dengan guru dan teman; Berpakaian seragam rapi sesuai aturan; Berkata jujur, lemah lembut, dan sopan terhadap guru dan sesama siswa. Menjenguk teman yang sakit. Dan dianjurkan setiap ada salah satu siswa yang ditimpa musibah agar siswa yang lain ber-empati dan membantu semampunya; dan Membiasakan Senyum, Sapa, Salam, Salim dan Santun (5S). Semua kegiatan ini sebagai sarana untuk menunjang pembentukan karakter peserta didik yang seimbang antara iman taqwa (Imtaq) serta ilmu pengetahuan dan teknologi (Iptek) sehingga terwujudnya peserta didik yang unggul.

\section{Respons Warga Sekolah Terhadap Pengembangan Kurikulum PAI Berbasis Pesantren}

Pengembangan kurikulum PAI berbasis pesantren melalui mata pelajaran P3AI telah mendapat respon positif dari peserta didik maupun orang tua. Pengajaran PAI sangat menarik bagi siswa karena tidak hanya diajarkan di dalam kelas tetapi juga di luar kelas dengan metode pengajaran yang bervariasi (Saputra, 2012). Mata pelajaran P3AI diajarkan melalui penambahan 8 jam pelajaran per Minggu. Indikatornya: 1) peserta didik hadir tepat waktu; 2) orang tua siswa merasa senang terhadap kegiatan keagamaan sekolah; 3) adanya kerjasama antara orang tua siswa dengan sekolah untuk dalam rangka meningkatkan ubbudiyah dan akhlakul karimah peserta didik; 4) peran aktif orang tua siswa untuk menjaga anak-anaknya dalam pergaulan bebas, narkoba dan kenakalan remaja.

Adanya respon positif terhadap penyelenggaraan pendidikan agama Islam dikalangan siswa sebagai gambaran untuk mencegah radikalisme di kalangan pelajar dengan menanamkan nilai-nilai budaya damai yang terkandung dalam nilai-nilai demokrasi, nilai-nilai multikultural dan nilai-nilai kemanusiaan. Sehingga terwujudnya peserta didik yang dapat memelihara dan meningkatkan pengalamalan terhadap ajaran agama yang dianut dengan mengembangkan sikap toleransi antar umat beragama.

\section{Strategi Pengembangan kurikulum Moderasi Beragama Berbasis Pondok Pesantren}

Strategi pengembangan kurikulum PAI bernuansa moderasi beragama dilakukan melalui kegiatan pembiasaan yang merupakan pembentukan akhlak dan penanaman/pengamalan ajaran Islam dalam kehidupan sehari-hari di sekolah dan di rumah. Adapun kegiatan pembiasaan meliputi: Peringatan Hari-hari besar Islam (Tahun Baru Hijriah, Isro' Mi'roj Nabi Muhammad SAW, Maulid Nabi Muhammad SAW, Idul adha, Idul fitri, Halal Bihalal dan Penanaman akhlakul Karimah, Sholat Dhuha, Sholat Dzuhur, Sholat Ashar dan Sholat Jumat berjamaah, Pembacaan dzikir berjamaah, Berdoa sebelum pelajaran dimulai dan sebelum pulang, Dilanjukan seteh berdoa sebelum memulai pelajaran dilakukan memebaca Al Quran secara bersama-sama selama 10 menit. Membiasakan berjabat tangan dengan guru dan teman, Berpakaian seragam rapi, Berkata jujur, lemah lembut, dan sopan, Menjenguk teman yang sakit dan mmbiasakan senyum, sapa, salam, salim dan santun.

Kurikulum yang dikembangkan di SMA Ciledug Al Musaddadiyah sudah terintegrasi antara kurikulum nasional dengan kurikulum pesantren dengan menggunakan jam tersendiri. Caranya dengan mengurangi jam kurikulum nasional pada mata pelajaran umum dengan memasukan kurikulum pesantren. Pada saat ini pengurangan jam pada mata pelajaran matematika dan sejarah. 
Integrasi pendidikan moderasi beragama dalam kurikulum PAI sebagai pelengkap dari pelajaran PAI untuk menguatkan karakter peserta didik. Pendidikan moderasi beragama mendorong peserta didik memiliki nilai nilai kerukunan dan penghormatan kepada orang lain serta dapat menerima dan menghormati perbedaan.

\section{Implementasi Kurikulum PAI Dalam Kegiatan Pembelajaran}

Pelaksanaan kurikulum PAI dalam kegiatan pembelajaran di SMA Ciledug Al Musaddadiyah Garut dilakukan menyatu dengan program pondok pesantren, mencakup: program Fiqh Ibadah, Tahfidz, BTQ, dan Aswaja. Dalam pelaksanaannya, pembelajaran PAI diberikan penguatan-penguatan melalui berbagai kegiatan seperti: praktek ibadah seperti praktek salat duha, salat duhur, salat ashar; bimbingan hafal al-Quran 3 juzz; ahlusunnah waljamaah (Aswaja), mengikuti sunah nabi Muhammad SAW; pendampingan Baca Tulis Al Quran (BTQ); pembiasaan Do'a sebelum pelajaran dimulai khususnya pembelajaran PAI; pakaian berjilbab wajib bagi peserta didik perempuan dan pendistribusian zakat ke masyarakat. Berbagai kegiatan tersebut diatas ditujukan untuk meningkatkan mutu pendidikan pengamalan terhadap ajaran agama yang dianut dalam rangka mewujudkan peserta didik yang yang memiliki sikap dan perilaku yang religius

\section{Moderasi Beragama Melalui Inovasi Kurikulum PAI}

Pelaksanaan moderasi beragama harus diterapkan di lingkungan pendidikan dalam pembentukan sikap moderat dalam beragama bagi peserta didik. Untuk itu perlunya pengembangan kurikulum PAI di sekolah berbasis pesantren yang mengajarkan moderasi Islam pendidikan pesantren untuk menghadirkan gerakan Islam moderat di kalangan peserta didik yang mengembangkan ajaran: (1) untuk membangun kerukunan (toleransi) di antara kelompok-kelompok yang berbeda, baik di luar Islam maupun di dalam Islam itu sendiri; (2) menebarkan perdamaian di lingkungan sosialnya; (3) mengedepankan dialog antar agama dan (4) menanamkan sikap keterbukaan dengan fihak luar dan 4) menolak ujaran kebencian (hoax) baik didalam dan luar sekolah (Hamid Hasan, 2008).

Moderasi Islam merupakan pemahaman Islam moderat, dengan gagasan menentang segala bentuk kekerasan, melawan fanatisme, ekstrimisme, menolak intimidasi, terorisme dan ujatan kebencian. Moderasi Islam adalah Islam yang toleran, damai dan santun, tidak menghendaki terjadinya konflik serta tidak memaksakan kehendak

Moderasi Islam akan menempatkan Islam sebagai solusi terhadap masalah-masalah sosial kemanusiaan menurut ruang dan waktu. Islam harus dapat menjawab berbagai tantangan modernitas yang semakin komplek, namun tetap berpegang kepoada tradisi masa lalu dan bias menerima nilai-nilai baru yang lebih baik.

Dalam pendidikan moderasi Islam, siswa tidak diperkenankan mengikuti jalan orangorang yang berlebih-lebihan. Tetapi diperintahkan untuk mengikuti jalan moderat yang lurus dan tidak menyimpang sesuai jalan yang ditempuh oleh para Nabi Muhammad SAW dan sahabatnya bukan jalan orang-orang yang dimurkai oleh Allah dan bukan pula jalan orang-orang yang berada dalam kesesatan. Pendidikan agama Islam mengajarkan nilai-nilai toleransi, menghormati para penganut agama lain dan saling menghormati dalam kehidupan masyarakat. Hal ini menunjukkan betapa pentingnya pendidikan moderasi beragama bagi peserta dalam kehidupan sehari-hari

\section{PENUTUP}

Berdasarkan uraian di atas penelitian ini menghasilkan kesimpulan sebagai berikut: (a) Penyelenggaraan pendidikan SMA Ciledug Al Musaddadiyah Garut berdasarkan nilai-nilai ke Islaman untuk mewujudkan anak sholeh; (b) Model moderasi beragama dalam penyelenggaraan PAI di SMA Ciledug Al Musaddadiyah Garut melalui pengembangan kurikulum PAI berbasis pesantren dalam bentuk mata pelajaran P3AI yang mengajarkan moderasi Islam untuk menghadirkan gerakan Islam moderat di kalangan peserta didik yang mengembangkan ajaran: (1) untuk membangun kerukunan (toleransi) di antara kelompokkelompok yang berbeda, baik di luar Islam maupun di dalam Islam itu sendiri; 
menebarkan perdamaian di lingkungan sosialnya; (3) mengedepankan dialog antar agama dan (4) menanamkan sikap keterbukaan dengan fihak luar dan 4) menolak ujaran kebencian (hoax) baik didalam dan luar sekolah. Terdapat tiga materi penting PAI dalam mewujudkan anak sholeh, yaitu: a) Fiqh Ibadah: Wudhu,Tata cara sholat, bimbingan bagi siswa tentang tata cara sholat yang benar, Saum, Ke-NU-an; b) Pembimbingan BTQ, Bagi siswa yang belum bisa baca Al Qur'an diberi pembinaan oleh guru PAI sesuai tingkatan kemampuan siswa dan c) Pembiasaan Berperilaku Mulia (Akhlakul Karimah) dilakukan melalui kegiatan: Sholat Dhuha, Dzuhur, Ashar dan Sholat Jumat berjamaah; Pembacaan dzikir berjamaah setelah shalat; Berdoa sebelum pelajaran dimulai dan sebelum pulang. Sebelum pembelajaran di mulai siswa berdoa bersama terlebih dahulu, diawali membaca fatihah dan iqrar serta doa mulai belajar. Membiasakan berjabat tangan dengan guru dan teman; Berpakaian seragam rapi sesuai aturan; Berkata jujur, lemah lembut, dan sopan terhadap guru dan sesama siswa. Menjenguk teman yang sakit. Dan dianjurkan setiap ada salah satu siswa yang ditimpa musibah agar siswa yang lain ber-empati dan membantu semampunya; dan Membiasakan Senyum, Sapa, Salam, Salim dan Santun (5S). Strategi pengembangan kurikulum PAI bernuansa moderasi beragama dilakukan melalui kegiatan pembiasaan oleh seluruh warga sekolah dalam rangka pembentukan akhlak dan penanaman/pengamalan ajaran Islam dalam kehidupan sehari-hari di sekolah dan di rumah. Namun kesadaran pembiasaan pengamalan akhlalk mulia pada seluruh warga sekolah dalam kehidupan sehari hari di sekolah masih perlu ditingkatkan; (c) Arah kebijakan pengembangan moderasi beragama. Pengembangan moderasi beragama di sekolah dalam rangka pembentukan sikap moderat dalam beragama bagi peserta didik. Untuk itu perlunya pengembangan kurikulum PAI di sekolah berbasis pesantren yang mengajarkan moderasi Islam pendidikan pesantren untuk menghadirkan gerakan Islam moderat di kalangan peserta didik yang mengembangkan ajaran: (1) untuk membangun kerukunan (toleransi) di antara kelompok-kelompok yang berbeda, baik di luar Islam maupun di dalam
Islam itu sendiri; (2) menebarkan perdamaian di lingkungan sosialnya; (3) mengedepankan dialog antar agama dan (4) menanamkan sikap keterbukaan dengan fihak luar dan 4) menolak ujaran kebencian (hoax) baik didalam dan luar sekolah; (d) Tidak ditemukan pandangan dan sikap keagamaan warga SMA Ciledug AlMusaddadiyah Garut yang radikal; $€$ Model pendidikan yang dikembangkan SMA Ciledug Al-Musaddadiyah Garut mengajarkan moderasi Islam untuk menanamkan sikap keterbukaan dan membangun kerukunan di antara kelompok-kelompok yang berbeda.

Untuk rekomendasi penelitian ini, yaitu pentingnya mengajarkan dan mengamalkan moderasi Islam untuk menghadirkan gerakan Islam moderat di kalangan peserta didik, perlu pembiasaan berperilaku mulia untuk membentuk peserta didik yang berakhlakul karimah, perlu ada koordinasi yang inten antara sekolah dengan pondok pesantren $\mathrm{Al}$ Musaddadiyah untuk memantau pelaksanaan pendidikan moderasi beragama dalam pendidikan agama Islam, dan strategi penerapan integrasi moderasi beragama di sekolah lebih pada upaya mengkondisikan suasana lingkungan sekolah yang lebih agamis.

\section{UCAPAN TERIMAKASIH}

Kegiatan Penelitian ini dapat berjalan lancar karena keterlibatan dan batuan berbagai pihak. Oleh karena itu, selaku peneliti kami mengucapkan terima kasih yang sebesarbesarnya kepada: a) Kepala Puslitbang Pendidikan Agama dan Keagamaan yang telah memberikan pengarahan dalam penyusunan dan pembahasan DO dan IPD; b) para narasumber, peneliti lainnya yang telah memberikan masukan, saran serta kritik dalam pembahasan DO dan IPD; c) Para pembantu lapangan dan d) seluruh responden (Ketua Yayasan, Kepala Sekolah, Waka Kurikulum, Waka Kesiswaan, Humas SMA Ciledug Al Musaddadiyah Garut) dan Toloh Masyarakat.

\section{DAFTAR PUSTAKA}

Agama, D. (2019) Moderasi Beragama. Jakarta: Badan Penelitian dan Pengembangan Kementerian Agama RI.

Aziz, A. (2020) 'Akar Moderasi Beragama Di Pesantren (Studi Kasus di Ma'had Aly 
Sukorejo Situbondo dalam Terbentuknya Nilai-Nilai Moderasi Beragama)', ArRisalah: Media Keislaman, Pendidikan dan Hukum Islam, 18(1), p. 142. doi: 10.29062/arrisalah.v18i1.348.

Creswell, J. W. (2014) Research Design; Pendekatan Kualitatif, Kuantitatif, dan Mixed. Yogjakarta: Pustaka Pelajar.

Deepwell, F. (2002) 'Towards Capturing Complexity: an interactive framework for institutional evaluation', Educational Technology \& Society 5 (3), 3.

Hamid Hasan, S. (2008) Evaluasi Kurikulum. Bandung: Remaja Rosdakarya.

Handayani, T. (2017) 'Potensi dan Kendala Program Wajib Belajar Sembilan Tahun di Pesantren: Kasus di Kabupaten Bangkalan', EDUKASI: Jurnal Penelitian Pendidikan Agama dan Keagamaan, 6(3). doi: 10.32729/edukasi.v6i3.129.

Haryani, E. (2020) 'Pendidikan Moderasi Beragama Untuk Generasi Milenia: Studi Kasus Lone Wolf' Pada Anak di Medan', EDUKASI: Jurnal Penelitian Pendidikan Agama dan Keagamaan, 18(2). doi: 10.32729/edukasi.v18i2.710.

Kemenag, R. (2012) Statistik Pendidikan Islam. Jakarta: Direktorat Jenderal Pendidikan Islam.

Kemenag, R. (2014) Pedoman Supervisi Pondok Pesantren Salafiyah (Dalam Rangka Wajib Belajar Pendidikan Dasar). Jakarta: Direktorat Jenderal Pendidikan Islam.

Kemendikbud (2016) 'Kajian dan Pedoman Penguatan Pendidikan Karakter Tingkat Sekolah Dasar dan Sekolah Menengah Pertama', in.

Kemendikbud (2017) 'Modul Pelatihan Penguatan Pendidikan Karakter Bagi Komite Sekolah', in.

Mc, L. (2012) Radicalism: A Philosophical Study. New York: State University of
New York Press.

Misrawi, Z. (2010) Hadratussyaikh Hasyim Asy'ari Moderasi, Keutamaan dan Kebangsaan. Jakarta: PT. Kompas Media.

Purwanto, Y. et al. (2019) 'Internalisasi Nilai Moderasi Melalui Pendidikan Agama Islam di Perguruan Tinggi Umum', EDUKASI: Jurnal Penelitian Pendidikan Agama dan Keagamaan, 17(2). doi: 10.32729/edukasi.v17i2.605.

Qowaid, Q. (2013) 'Gejala Intoleransi Beragama di Kalangan Peserta Didik dan Upaya Penanggulangannya Melalui Pendidikan Agama Islam di Sekolah', Dialog, 1(36), pp. 71-86.

Rhozin, W. (2017) 'Pondok Pesantren Salafiyah Dan Penuntasan Wmib Belmar', EDUKASI: Jurnal Penelitian Pendidikan Agama dan Keagamaan, 3(4). doi: 10.32729/edukasi.v3i4.225.

Saputra, D. (2012) 'Evaluasi Pelaksanaan Program Wajar Dikdas Sembilan Tahun Pada Pondok Pesantren Salafiyah AlIman Pegayaman Sukasada Buleleng', Jurnal Administrasi Pendidikan Indonesia, 3(2). Available at: http://oldpasca.undiksha.ac.id/ejournal/index.php/jurnal_ap/article/view/ 394.

Setiyadi, A. C. (2012) 'Pendidikan Islam Dalam Lingkungan Globalisai, Jurnal University of Darusalam Gontor Vol.7 No.2 Desember, hal 252', 7, p. 252.

Suprapto, S. (2017) 'Budaya Sekolah, Motivasi Belajar dan Mutu Pendidikan Agama Islam', Edukasi. Indonesian Ministry of Religious Affairs, 6(4), p. 294421.

Trianto (2009) Mendesain Model Pembelajaran Inovatif-Progres. Jakarta: Kencana Prenada Media Group.

Yasid, A. (2014) Islam Moderat. Jakarta: Erlangga. 